University of Minnesota Morris Digital Well

University of Minnesota Morris Digital Well

English Publications

Faculty and Staff Scholarship

Summer 2003

\title{
Conrad Scholarship Under New-Millennium Western Eyes
}

Michael Lackey

University of Minnesota Morris, lacke010@morris.umn.edu

Follow this and additional works at: https://digitalcommons.morris.umn.edu/eng_facpubs

Part of the Literature in English, British Isles Commons

\section{Recommended Citation}

Lackey, Michael, "Conrad Scholarship Under New-Millennium Western Eyes" (2003). English Publications. 22.

https://digitalcommons.morris.umn.edu/eng_facpubs/22

This Book Review is brought to you for free and open access by the Faculty and Staff Scholarship at University of Minnesota Morris Digital Well. It has been accepted for inclusion in English Publications by an authorized administrator of University of Minnesota Morris Digital Well. For more information, please contact skulann@morris.umn.edu. 
Review: Conrad Scholarship Under New-Millennium Western Eyes

Reviewed Work(s): Conrad and Masculinity by Andrew Michael Roberts; Envisioning Africa: Racism and Imperialism in Conrad's Heart of Darkness by Peter Edgerly Firchowd; Conrad and Impressionism by John G. Peters; Space, Conrad, and Modernity by Con Coroneos

Review by: Michael Lackey

Source: Journal of Modern Literature, Vol. 26, No. 3/4 (Summer, 2003), pp. 143-147

Published by: Indiana University Press

Stable URL: https://www.jstor.org/stable/30053237

Accessed: 06-03-2020 21:07 UTC

JSTOR is a not-for-profit service that helps scholars, researchers, and students discover, use, and build upon a wide range of content in a trusted digital archive. We use information technology and tools to increase productivity and facilitate new forms of scholarship. For more information about JSTOR, please contact support@jstor.org.

Your use of the JSTOR archive indicates your acceptance of the Terms \& Conditions of Use, available at https://about.jstor.org/terms

Indiana University Press is collaborating with JSTOR to digitize, preserve and extend access to Journal of Modern Literature 


\title{
Conrad Scholarship Under New-Millennium Western Eyes
}

\author{
Michael Lackey \\ New York SU, Brockport
}

Andrew Michael Roberts. Conrad and Masculinity. St. Martin's Press, Inc., 2000. xi +250 pp. $\$ 55.00$.

Peter Edgerly Firchowd. Envisioning Africa: Racism and Imperialism in Conrad's Heart of Darkness. University Press of Kentucky, 2000. xvi +258 pp. \$34.95.

John G. Peters. Conrad and Impressionism. Cambridge University Press, 2001. xiii +206 pp. $\$ 60.00$.

Con Coroneos, Space, Conrad, and Modernity. Oxford University Press, 2002. 199 pp. \$65.00.

If radical developments in Marxism, poststructuralism, feminism, and postcolonialism have posed serious challenges to traditional approaches to literary studies, then Conrad and Conrad scholars have proven to be more instead of less relevant with each new intellectual development. The recent studies on Conrad, which so deftly incorporate contemporary theory into their interpretations, are perfect cases in point. These studies, rather than being narrow and trendy, bring together a variety of theories in an attempt to honor the complexity and integrity of Conrad's texts.

Perhaps the least compelling of the recent studies is Space, Conrad, and Modernity, which could have easily been titled Laughter, Foucault, and Postmodernity or Frontiers, Language, and Mysticism. This is a book that wanders from one thought to the next, making brief reference to a myriad of modernists and postmodernists, poets and philosophers, mystics and anarchists, but is ultimately less successful than it could have been. The primary problem with this book is its method of analysis, which usually consists of dense forays into theory and then brief reference to a Conrad text. Unfortunately, neither the theoretical approach nor the textual analyses are sufficiently developed. This weakness occasions much disappointment, for the content of this book promises to yield much insight into Conrad and modernism.

Michael Lackey, "Conrad Scholarship Under New-Millennium Western Eyes," Journal of Modern Literature, 26.3/4 (Spring 2003), pp. 143-147. (C) Indiana University Press, 2004. 
Coroneos's main argument: in contrast to the time-oriented approaches to modernism, Coroneos focuses on the "space of things." One of the primary problems that modernists had to confront was the emergence of "closed space," which is defined as "a world in which all earthly space is charted, claimed, interconnected, creating a "closed political system"' (15). In addition to the emergence of closed space is the complication arising from the linguistic turn in the western intellectual tradition, which has effectively blurred the distinction between sign and referent. Given all these developments, Coroneos sets his book "on the shadow-line between the space of things and the space of words" (16).

This focus on space is fascinating and insightful, certainly a topic that could shed considerable light on both Conrad and modernism. But there is a lack of focus in this short book. There are intelligent discussions of the "real scandal of Galileo" (31), "the real scandal of Foucault's own work" (37), and the "scientific scandal" of "the desiring heart" (44). I found myself especially enthralled by a compelling interpretation of Angela Carter's The Bloody Chamber (39-41), an enlightening discussion of anarchist geography (49-57), and an insightful analysis of philosophy's inability to grasp laughter (150-54). Given the overwhelming complexity of these extremely diverse ideas, it is little wonder that Coroneos had some difficulties bringing all of the material into a single constellation of thought.

Despite the overall lack of focus in this book, there are some excellent observations throughout. By reading The Secret Agent in light of developments in anarchist geography, Coroneos intelligently argues that "Conrad's most urban novel reveals a peculiar secret: the existence of an 'open' space embedded within a 'closed' one" (57), and by reading Under Western Eyes in light of "a beguiling opposition between Russian mysticism and Western reason" (102), Coroneos does a compelling analysis of the psychology of 'Russianness' in Conrad's novel, a psychology that illuminates Conrad's politics. However, these interpretations, while insightful, are only suggestive, and as a consequence, I suspect that many Conrad scholars will be neither convinced nor satisfied. Of course, it is possible that Coroneos merely intended to initiate a dialogue that would take many years to exhaust. If so, we will judge Coroneos's book more positively in light of the studies that it will generate. But for now, the book is more tantalizing than satisfying.

A more thorough study is Envisioning Africa, which is certain to evoke passionate responses, especially from postcolonial scholars. Firchow has taken it upon himself to defend Conrad from the charge of being a "bloody racist," so he spends considerable time and effort outlining the historical and political context in which Heart of Darkness was written in order to demonstrate that Conrad could not have been racist in the strong sense of the word because "nowhere in the novel does Conrad or any of his narrators, personified or otherwise, claim superiority on the part of Europeans on the grounds of alleged genetic or biological difference" (10). If Conrad or his novel is racist, Firchow argues, it is only in a weak sense since Heart of Darkness acknowledges racial distinctions "but does not suggest an essential superiority" (11) of any particular group.

More than anything else, what angers Firchow about contemporary Conrad scholarship is the overzealous postcolonial interpretation, which overstates the crimes of Western Imperialism and idealizes pre-colonial Africa. Specifically, Firchow argues that moral indignation has gotten the better of scholars like Edward Said, Chinua Achebe, and Patrick Brantlinger, who offer little to no evidence for calling Conrad and his novel racist and pro-Imperialist. To refute the generally accepted postcolonial interpretation, Firchow argues 1) that most Congolese during King Leopold's "Administration" died of sickness and starvation rather than being brutally murdered, 2) that neither 
Marlow nor turn-of-the-century Europeans sanctioned Kurtz's extreme practices in the Congo, 3) that Marlow's view of Africans is sympathetic rather than racist, and 4) that Marlow sympathizes with the "original" Kurtz of high ideals rather than the "sham" Kurtz who shows no restraints. For Firchow, both the horrors of Western colonization and the message of Heart of Darkness are bleak enough as they are, so there is no need to overstate the facts or the message. Indeed, overstating the case is to re-enact Marlow's concluding lie to Kurtz's Intended, and as far as Firchow is concerned, contemporary scholarship is already complicit in this large-scale project of deception.

Despite Firchow's unnecessary, condescending, and annoying remarks about contemporary Conrad scholars and literary theorists (he refers to "that subspecies of humankind known as the literary critics" [164]), there is something refreshing about this book. Firchow refuses to embellish the facts. No matter how uncomfortable or unpopular, he insists on representing Conrad and his work as accurately as he can in light of the available information. For Firchow, Conrad is no prophetic figure who totally overcame the racist and imperialist prejudices of his culture, neither is he a bloody racist or imperialist who tried to perpetuate a wicked doctrine of European superiority and African inferiority. Rather, Conrad is a complex writer who struggled to understand the moral complexities of human living.

While Firchow certainly makes a compelling case for revising many postcolonial interpretations of Conrad and Heart of Darkness, I find myself not entirely convinced by Envisioning Africa. The overt horrors of colonization (dispossessing people of their land and culture, forced labor, the inevitable violence, etc.) are bad enough, but if we understand the pernicious psychological consequences of one superpower dominating a land and a people, the devastating consequences of colonization take on a whole new form. As Frantz Fanon claims, living as a colonized person in a colonized country leads - almost inevitably - to some form of psychosis. If we understand postcolonial theory in this more subtle psychological sense (and it is significant that Firchow never mentions Fanon), then Firchow's critique, specifically of Said, would be less compelling. There is an even more important reason to take issue with Firchow. On his interpretation, Marlow and Conrad almost always speak in the same voice. So if it could be shown that Marlow is a racist, then we could conclude that Conrad is a racist. But if we interpret Heart of Darkness as Conrad's indictment of the subtle psychology of imperialism and racism, which is alternately embodied in the characters of Marlow and Kurtz, then the novel would appeal to both Firchow and postcolonial scholars.

A more balanced approach to Conrad scholarship is to be found in Conrad and Impressionism, a book that will prove to be an extremely valuable study to modernist and Conrad scholars with a philosophical orientation. In this book, Peters claims that creative artists of the late-nineteenth and early-twentieth centuries began to reject the objective claims of positivism and the solipsistic tendencies of idealism. The result was impressionism, an epistemological approach to the world that takes into account the solidity of objects in the external world and the power of the mind to construct 'reality.' According to an impressionist epistemology, 'truth' is to be found, not in the one-sidedness of "positivism and idealism," but in the "two-sided exchange" of impressionism.

Central to Peters' project is a distinction between two types of perception. "Primitive perception represents an initial sense impression before the observer organizes it into a meaning that accords with past experience, while civilized perception represents the impression after the observer organizes the initial experience and ascribes meaning to it" (37). Human meaning exists only in the world of civilized perception, which means that meaning is not ontologically inherent but culturally constructed. After using this epistemological model to shed considerable light on many of Conrad's 
texts, Peters claims that in Conrad's world "our perceptual experience and objective knowledge are both individual and relative and that knowledge of objects and events cannot be universalized" (60). This sounds a bit trendy, but neither Conrad nor Peters are comfortable with this epistemological state of affairs. Both solipsism and ethical anarchy loom large when "no absolutes exist," so Conrad's task is to formulate an acceptable vision of human living "in a universe" that is "irrational and indifferent to human beings" (133).

After rejecting both objective Truth and ethical anarchy, Conrad is left with the difficult task of articulating a political vision of "responsible social interaction" (121). If Peters is right, and there is much textual evidence to suggest that he is, then Conrad succeeded in constructing this vision by formulating an impressionist theory of knowledge. According to this model, "the human being is the building block from which Conrad then constructs his world" (134). On this interpretation, Conrad neither blindly accepts nor totally rejects traditional western values. Indeed, Conrad is frequently critical of the western worldview, mainly because its unrealistic and unrealizable ideals "de-emphasize humanity" (145), but he clings to many of these values nonetheless, so long as they are never converted into a fixed idea or an absolute Truth. What matters most for Conrad is a human community that affirms the human and provides "for orderly social interaction" (140).

Conrad and Impressionism is a first-rate study. However, there are a couple issues that must give readers pause. On Peters' reading of Conrad, "none can bear the light of western ideals" (83), because "western ideals are at odds with human experience" (84). Yet Conrad accepts these ideals, Peters claims, as long as they are never treated as an absolute or universal. But if it can be shown that one of the primary ideals, if not the most fundamental one, of the western tradition is certain knowledge of an absolute and universal Truth, then Conrad's hostility toward western ideals would be a little more extreme than Peters' book suggests. Second, if it could be shown that many 'noble ideals' of the west effectively justify a political system of dominance and degradation of the 'barbaric' and 'uncivilized' Other, then Conrad's seeming adherence to many of the west's ideals, whether relative or absolute, would make Conrad - unwittingly - a supporter of a profoundly offensive political vision.

Of the new millennium Conrad studies, Roberts's Conrad and Masculinity is the most challenging and original, a book that brilliantly illuminates Conrad's corpus; modernist views of sexuality, imperialism and epistemology; and contemporary theoretical approaches like feminism, poststructuralism, and postcolonialism. Roberts's intellectual range is stunning, which makes it difficult to reduce his achievements in this book to any single idea. By using the linkage between imperialism and the death drive to interpret "Conrad's self-destructive anti-heroes" (22), by suggesting "a structure in which the crisis of masculinity at home [in Britain] operates as the unconscious of the imperial novel" (61), and by analyzing the way the male homosocial economy allows men to exchange women and knowledge like commodities, Roberts offers a number of compelling ways to read some of the most ambiguous scenes and passages in Conrad's fiction.

Perhaps most refreshing in Roberts's approach is his refusal to assume a judgmental stance or to use a narrow theoretical lens when interpreting texts. Roberts does not use theory to indict or exonerate Conrad, the novels or characters; rather, by examining how ambivalent ideologies like imperialism and patriarchy are at odds with themselves, he exposes the central tensions and conflicts driving Conrad's novels and characters. For example, Roberts does a first-rate analysis of Foucault's discussion of the socio-political shift from the coercive power of pre-modern society to the disciplined bodies of modern society. Modernist society had to develop extremely sophisticated 
psychological and political structures in order to subject specific individuals within the culture into subservient roles. By examining how State Apparatuses have gendered bodies, Roberts intelligently articulates how characters in Nostromo "find themselves trapped within systems of meaning which determine them" (109). On this interpretation, Nostromo thematizes the social and historical shift from a pre-modern to a modern society and thereby documents how modern society replicates the systems of injustice and oppression that it seemingly abolished.

To develop this interpretation, Roberts relies heavily on a complex theory that incorporates various elements of feminism, Marxism, poststructuralism, and postcolonialism, and therein lies his strength. Through his commanding grasp of various contemporary theories, Roberts offers an impressive interpretation of Conrad's representation of patriarchal systems of domination and the disenfranchised person's marginalization. Just as compelling is his appropriation of film theory, which he uses to analyze "the power/vision nexus" (172) and "the gendering of the visual" (176) in Conrad's fiction, or his unique reworking of Lacan's gaze/look distinction, which he uses to examine the masculine homosocial economy in the novels. These various theories he uses, not to idealize the disempowered through a retrospective analysis of culturally marginalized groups, but to identify the sophisticated psychological, political, and cultural mechanisms of disempowerment. Given the strength of his analysis and the depth of his insight, we will be consulting Roberts's book for many years to come for unique ways of understanding the most complicated passages and characters in Conrad's texts.

Consistent among these recent studies is a focus on epistemology, which is to be expected given Conrad's preoccupation with unreliable knowledge and untrustworthy perception. What makes these studies so valuable, however, are the variety of approaches used to illuminate the distinctive features of Conrad's epistemology - space, postcolonialism, existentialism, primitive perception, gender, queer theory, poststructuralism, and others. While the recent studies do not resolve the all-important epistemological dilemmas in Conrad's texts, they do carry on the Conradian tradition of perpetual questioning and honest inquiry in the name of social justice. 